\title{
Enrichment of nutritional value of Phyllanthus emblica fruit juice using the probiotic bacterium, Lactobacillus paracasei HII01 mediated fermentation
}

\author{
Sartjin PEERAJAN ${ }^{1}$, Chaiyavat CHAIYASUT², Sasithorn SIRILUN ${ }^{2}$, Khontaros CHAIYASUT $^{1}$, \\ Periyanaina KESIKA², Bhagavathi Sundaram SIVAMARUTHI ${ }^{2 \star}$
}

\begin{abstract}
The fermented herbal juices are capable of curing and preventing diseases and reducing the aging progress. The present study was performed to investigate the fermentation of Phyllanthus emblica fruit by Lactobacillus paracasei HII01 with respect to carbon sources, polyphenols, and antioxidant properties. The physical changes, for instance, color, odor, taste, turbidity and gas formation, throughout the fermentation process was manually monitored. The fermented product was rich in polyphenolic content. The acid content and $\mathrm{pH}$ of the product were under the norms of Thai community product standards. Antioxidant properties of the fermented product were proved using ABTS, and FRAP assays. Chelation based study suggested that fermented P. emblica fruit juices are healthy enough to stabilize the oxidized form of the metal ion. The optimum fermentation period was 15 days. All the results supported that studied carbon sources did not interfere with the quality of the product. This report is the prelude study on the use of probiotic starter culture for the production of $P$. emblica fruit based lactic acid bacteria fermented beverages (LAFB) enriched with bioactive compounds. Further research on the impact of different carbon sources and upstream processes on the quality of LAFB is currently in progress.
\end{abstract}

Keywords: antioxidant; lactic acid bacteria fermented beverages; Lactobacillus paracasei; Phyllanthus emblica fruit; polyphenol.

Practical Application: Development and characterization of probiotic-based fermented P. emblica fruit juice as health supplement.

\section{Introduction}

Fermented herbal juices are widely consumed all over the world especially in Thailand. Thai people believe that these herbal juices can prevent and cure disease, and are supplemented as a health promoting beverage said to have anti-aging properties. Lactic acid bacteria (LAB) fermented beverages (LAFB) such as EM-X, fermented soybean broth, and Kefir have been widely used by world population. EM-X is an antioxidant beverage prepared by fermentation of papaya, unpolished rice, and seaweeds with the help of effective microbes such as photosynthetic bacteria, LAB, and yeast (Ekpeghere et al., 2012). It is accepted in clinical practices and is recommended as a prophylactic beverage used for the cure of various infectious diseases, allergies, cancer, diabetes, hypertension, and rheumatism (Deiana et al., 2002). Fermented Soybean broth is reported to be rich in antioxidant property (Yang et al., 2000; Romero et al., 2004). Kefir is a fermented milk product and is believed to contain efficient substances (La Rivière \& Kooiman, 1967; Arslan, 2015). Several LAB such as Lactobacillus kefiri, L. paracasei (Gao et al., 2015), L. plantarum, L. satsumensis (Miguel et al., 2010), L. lactis (Bergmann et al., 2010), L. brevis, Leuconostoc mesenteroides, and yeasts such as Kluyveromyces marxianus, K. wickerhamii, Pichia angusta, P. guilliermondii have been identified in kefir grains (Kıvanç \& Yapic1, 2015). In the kefir grains, LAB and yeast are surrounded by slimy polysaccharide matrix called kefiran (Rodrigues et al.,
2005). LAB present in the kefir produces lactic acid, acetaldehyde, and several kind of bacteriocins, which delays and inhibits the pathogenic bacteria (Bacillus cereus, Clostridium tyributyricum, Escherichia coli, Listeria monocytogenes, and Staphylococcus aureus) contamination (Kıvanç \& Yapıc1, 2015). Many strains of Lactic acid bacteria like $L$. paracase $i, L$. plantarum (Altay et al., 2013), L. pentosus, L. brevis, L. fermentum, L. casei, L. kimchi, L. fallax, Weissella confusa, W. koreenis, W. cibaria, and Pediococcus pentosaceus are used in various fermented foods (Swain et al., 2014). Lactobacillus paracasei subsp. paracasei NTU 101 and its fermented products have been reported for its beneficial effects in preventing hyperlipidemia-induced oxidative stress and atherosclerosis, and reduces the blood pressure (Chiang \& Pan, 2012). Chen et al. (2015) have revealed that L. paracasei 01 fermented milk beverage as a functional food in strengthening the intestinal barrier by protecting the intestinal epithelial cells. Mostly L. paracasei have been reported for its multiprobiotic activity (Wassenberg et al., 2011; Chiang \& Pan, 2012; Pellaton et al., 2012; Chen et al., 2015). Therefore, this study have focused on L. paracasei as a starter culture for LAFB.

In traditional Thai medicine, several plants are used entirely or its parts as a source of antioxidants. Among which, Phyllanthus emblica fruit (also named as Emblica officinalis) is well known 
for its potent antioxidant properties. P. emblica fruits are pale green or yellowish brown endocarp in color from the medium sized tree. Dried P. emblica fruits are used in Ayurvedic Hindu traditional medicine, Unani, conventional medicine practices in middle-east and south-Asian countries, systems of medicine in various treatments for fever, liver disorders, indigestion, anemia, and urinary complications. P. emblica fruits are rich in vitamin- $C$, which is readily absorbed by the human digestive system. Thus, they are used for the treatment of scurvy and pulmonary tuberculosis. P. emblica fruit juice can also be used to treat diarrhea, dysentery, and some joint pains (Chevallier, 1996); and their fruits are known for its lipid peroxide inhibition property and scavenging nature of hydroxyl and superoxide radical (Jose \& Kuttan, 1995). P. emblica extracts can inhibit lipid peroxidation induced by gamma radiation in rat liver microsomes and superoxide dismutase (SOD) mediated damages in rat liver mitochondria (Khopde et al., 2001). Chatterjee et al. (2012) revealed that the role of gallic acid includes active fraction of $P$. emblica in ulcer healing through the endothelial nitric oxide synthase-dependent pathway. Few reports have detailed the chemical constituents and pharmacogenetic properties of P. emblica (Habib-ur-Rehman et al., 2007; Khosla \& Sharma, 2012). Colucci et al. (2015) reported that the oral supplementation of $P$. emblica fruit extracts enhances the effectiveness of treatments for vitiligo.

Fermentation of food is an ancient food processing technologies. The process, quality improvement, and duration of the fermentation are developed over the years. Even though, fermentation is an ancient bioprocess for making beverages and food preservation, the use of microorganism with known biology in bioprocess technology have emerged very recently (Ross et al., 2002). The fermented beverages prepared using medicinal plants are superior with respect to the antioxidant properties. The scientific data explaining the beneficial effect of LAFB made from P. emblica fruits are not adequate. Thus, the current study aimed to investigate the polyphenol content and antioxidant properties of fermented P. emblica fruit with $L$. paracasei, and different carbon sources. In addition, the factors affecting the preferred nature of $P$. emblica fruits based LAFB has been studied.

\section{Materials and methods}

\subsection{Raw materials, microbes, and experimental setup}

Fresh Phyllanthus emblica fruits were collected from amphur Maesareung, Maehongsorn province, Chiang Mai, Thailand. Cane sugar and honey were purchased from Chiang Mai market and Agricultural extension and development center, Chiang Mai, respectively. Prior to the fermentation process, fruits were cleaned with water and subjected to various treatments (data not shown) to remove resisting microbial contamination followed by mechanical crushing.

Lactobacillus paracasei HII01 was used as a starter culture, which was provided by Health Innovation Institute (HII). The fermentation was carried out as per the following batches with respective controls. Fermentation 1 (Fn-1): crushed P. emblica fruit + water + cane sugar and $10 \%(\mathrm{w} / \mathrm{w})$ of $L$. paracase $i$ as starter culture; Fermentation 2 (Fn-2): crushed P. emblica fruit + water + cane sugar; Fermentation 3 (Fn-3): crushed P. emblica fruit + water + honey and $10 \%(\mathrm{w} / \mathrm{w})$ of $L$. paracase $i$ as starter culture; Fermentation 4 (Fn-4): crushed P. emblica fruit + water + honey; Control 1 (Cl-1): water + cane sugar and $10 \%(\mathrm{w} / \mathrm{w})$ L. paracasei; Control 2 (Cl-2): water + cane sugar; Control 3 (Cl-3): water + honey and $10 \%(\mathrm{w} / \mathrm{w})$ of $L$. paracasei; Control 4 (Cl-4): water + honey. The Fn components were mixed with a ratio of 3:10:1 (w/v/w) of crushed P. emblica fruits, water, cane sugar or honey, respectively.

\subsection{Inoculum (starter culture) preparation, fermentation, and sample collection}

The probiotic strain, $L$. paracase $i$ was used as a starter for the fermentation process in this study. Single colony of L. paracasei was inoculated in $180 \mathrm{~mL}$ of MRS broth and incubated at $35-37^{\circ} \mathrm{C}$ for $12 \mathrm{~h}$. Then the culture was scaled up to 1.8 liter with approximate cell concentration of $10^{9} \mathrm{CFU} / \mathrm{mL}$. The fermentation process was carried out in polypropylene plastic reactor (18.9 liter) with airtight lock and other aseptic measures. The fermentation process was executed at $30 \pm 2{ }^{\circ} \mathrm{C}$ for six months. Samples were collected on day $0,4,7,10,15$, $20,30,45,60,75,90,120,150$, and 180 of fermentation and the physical properties of fermentation mixture (FnM) were noted. The collected samples were immediately filtered through Whatman no. 42 filter paper, prepared $1 \%(\mathrm{v} / \mathrm{v})$ of each sample with sterile water and stored at $-70^{\circ} \mathrm{C}$.

\subsection{Total polyphenolic content determination}

Total phenolic content of the samples were determined by the modified Folin-Ciocalteu colorimetric method of Kusirisin et al. (2009) and Yang et al. (2014). The reaction mixture was prepared by adding $100 \mu \mathrm{L}$ of Folin-Ciocalteu reagent, $1.5 \mathrm{~mL}$ of deionized water and $200 \mu \mathrm{L}$ of each sample or various concentration of gallic acid or pyrogallol. Then, the reaction was deactivated with $20 \%$ saturated sodium carbonate. The absorbance was measured at $725 \mathrm{~nm}$ after $30 \mathrm{~min}$ incubation at room temperature (RT). The total phenolic content was expressed as mg gallic acid and $\mathrm{mg}$ pyrogallol equivalents per $\mathrm{mL}$ of sample.

\subsection{Determination of organic acid profile and $\mathrm{pH}$}

The content of organic acids in the samples was assessed by high-performance liquid chromatography (HPLC). Twenty micro liter of filtered samples were used for analysis, and the separation was achieved by using Phenomenex C8 column $(250 \mathrm{~mm} \times 4.6 \mathrm{~mm}, 0.5 \mu \mathrm{m})$ (Advanced Chromatography Technologies, Scotland). Phosphate buffer (0.1 M, pH 2.1), at the flow rate of $0.8 \mathrm{~mL} / \mathrm{min}$ was served as the mobile phase. The organic acids concentration was determined by comparing the peak area of the sample with the area of standards (lactic acid, and acetic acid). The values lower than the limitations of detection were reported as not detected (ND). The values equal or higher than the limitation of quantity were also reported. $\mathrm{pH}$ of the sample, after filtration, was measured using the standard pH meter (Metrohm 691). 


\subsection{ABTS assay}

2, 2'-azino-bis-3-ethylbenzthiazoline-6-sulphonic acid (ABTS) assays were performed as per the modified method of Singhatong et al. (2010). Briefly, ABTS ${ }^{\bullet+}$ radical stock solution (7 mM ABTS and $2.45 \mathrm{mM}$ potassium persulfate) was prepared. The $\mathrm{ABTS}^{*+}$ working solution (2\%) was prepared using the deionized water with absorbance of $0.7 \pm 0.05$ at $734 \mathrm{~nm}$. $2 \mathrm{~mL}$ of $\mathrm{ABTS}^{\cdot+}$ working solution and $100 \mu \mathrm{L}$ of each sample or vitamin-C or trolox or quercetin was mixed and incubated at RT for $3 \mathrm{~min}$. The results are expressed as VCEAC (mg of vitamin-C equivalent antioxidant capacity), TEAC ( $\mathrm{mg}$ of trolox equivalent antioxidant capacity), and QEAC (mg of quercetin equivalent antioxidant capacity) per $\mathrm{mL}$ of sample.

\subsection{FRAP assay}

The FRAP assay was executed with slight modifications (Suwannalert et al., 2010). Briefly, $1.8 \mathrm{~mL}$ of FRAP reagent was mixed with $180 \mu \mathrm{L}$ of deionized water and $60 \mu \mathrm{L}$ of each sample or positive control. Then, the reaction mixture was incubated at RT for $4 \mathrm{~min}$. After incubation, the solution was subjected to spectrophotometric analysis at $539 \mathrm{~nm}$. Results were expressed as $\mathrm{mg} \mathrm{Fe} \mathrm{SO}_{4}$ equivalents per $\mathrm{mL}$ of sample.

\subsection{Ferrous Ion-chelating assay}

The complex formation of ferrous with constituents in the samples was studied by complexometry. The buffer systems used, to test the complex in different $\mathrm{pH}$ conditions, were hexamine buffers with $\mathrm{pH}$ of 3.6, 5.0, and 6.0. The absorbance spectrum for the maximum wavelength of reagent (Tetramethylmurexide ammonium salt (TMM) solution) and $\mathrm{TMM}-\mathrm{Fe}^{2+}$ complex were observed. The calibration curve for the various concentration of $\mathrm{Fe}^{2+}$ was measured (Decker \& Welch, 1990).

\subsection{Total peroxidase assay}

The activity of guaiacol peroxidase in the supernatant was determined spectrophotometrically. The reaction mixture contained $15 \mathrm{mM}$ guaiacol and $5 \mathrm{mM} \mathrm{H}_{2} \mathrm{O}_{2}$ in $0.1 \mathrm{M}$ phosphate buffer, $\mathrm{pH}$ 3.5. The sample $(500 \mu \mathrm{L})$ was added to the reaction mixture and incubated at $30^{\circ} \mathrm{C}$ for $15 \mathrm{~min}$. After the incubation period, the reaction was measured at $470 \mathrm{~nm}$ (Laloue et al., 1997).

\section{9 $\beta$-Glucosidase activity assay}

About $500 \mu \mathrm{L}$ of each sample were mixed with $1 \mathrm{mM}$ p-nitrophenyl- $\beta$-d-glucopyranoside (pNPG) and $0.1 \mathrm{M}$ phosphate-citrate buffer, $\mathrm{pH}$ 3.5. Then, the mixtures were incubated at $30^{\circ} \mathrm{C}$ for $20 \mathrm{~min}$. The reaction was arrested by the addition of $0.5 \mathrm{M}$ sodium carbonate and measured at $420 \mathrm{~nm}$ (McCue \& Shetty, 2004).

\subsection{Statistical analysis}

All the experiments performed in this study were carried out in triplicate. Analysis of variance (ANOVA) was carried out to measure the dissimilarities in antioxidant activities. Duncan's new multiple range test determined the significant differences, at the $95 \%$ confidential level $(p<0.05)$ by SPSS v.17 (Chicago, SPSS Inc, U.S.A).

\section{Results and discussion}

\subsection{Physical observations of the reaction}

Fermentation of $P$. emblica fruits was carried out with or without $L$. paracasei as a starter culture, as detailed in materials and method section. The physical changes, such as color, odor, taste, turbidity and gas formation, during the fermentation process were observed manually and tabulated (Supplementary Material, Table 1S). Color of the fermentation mixture (FnM) in Fn-1,2, and its respective controls Cl-1, 2 was dark brown, due to the presence of cane sugar, whereas FnM in Fn-3, 4, and Cl-3, 4 was pale yellow in color because of honey. The notable color change was not observed until 15 days. FnM in Fn-3, 4 and Cl-3, 4 turned dark yellow in color after 15 days. A possible reason for the darkened color is due to the resultant fermentation, but there was no change in color of the FnM in Fn-1, 2 and Cl-1, 2 throughout the process. The odor of the mixture was sour and pickled tamarind throughout the process. Bad odor was noticed in $\mathrm{Cl}-2$ starting from day 4 , which might be due to the growth of contaminated microbes. No bad odor was recognized from other reactors. Taste of the fermented $P$. emblica fruits was initially sweet and later turned into sour till the end of the process. The FnM was found as turbid throughout the process. Plenty of gas formation was observed in Fn-1, 2 and Cl-1, 2, whereas there is no noticeable level of gas formation in Fn-3, 4 and $\mathrm{Cl}-3,4$. This data indicated that during fermentation, the gas formation was due to the presence of raw cane sugar as a carbon source. So the fermentation process using cane sugar as one of the materials should follow the gas management protocol during the process. Filmy layer and bubbles were observed at the top of the FnM in Fn-2, 4 and Cl-2, 4 from $4^{\text {th }}$ day of the process and this filmy layer was found in the entire reactors after 60 days of the process. Alcoholic aroma was noticed in Fn-2, 4 and Cl-2, 4 after 60 days of the process. During the fermentation process, the mixture gets contaminated with yeast due to the lack of starter culture (Prachyakij et al., 2007; Kantachote \& Charernjiratrakul, 2008). Furthermore, yeast contamination results in alcohol production, which might be the possible reason for the alcoholic aroma of FnM in Fn-2, 4 and its respective control (Supplementary Material, Table 1S).

\subsection{Polyphenol content}

The polyphenolic content of the fermented product was kinetically analyzed using both gallic acid and pyrogallol as standards. Total polyphenol level was gradually increased until day 15 , and then the concentration was slowly reduced during the process. Increase in the amount of polyphenol content $(10.32 \pm 0.28 \mathrm{mg}$ gallic acid equivalent $/ \mathrm{mL}$, and $10.385 \pm 0.23 \mathrm{mg}$ pyrogallol equivalent/mL of Fn-1, respectively) was recorded at the $15^{\text {th }}$ day of fermentation (Figure 1). The decrease in polyphenolic content after 15 days might be due to the enzymatic oxidation of polyphenolic content by polyphenol oxidase.

This result revealed that 15 days fermentation process is good enough to enrich the product with polyphenolic content by selected substrate and starter culture. A recent study has reported the phenolic components extraction from $P$. emblica by comparing conventional and ultrasound-assisted extractions 

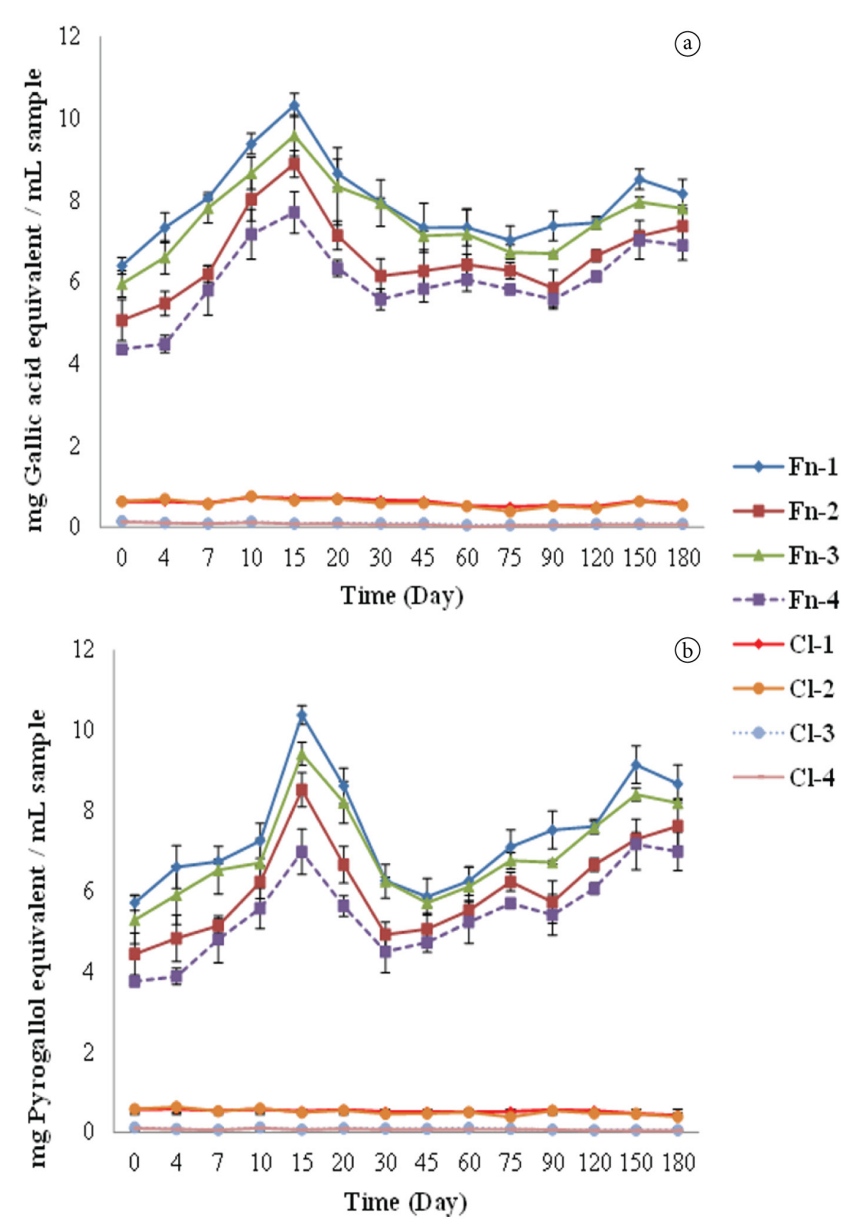

Figure 1. Polyphenolic contents of $P$. emblica juice during fermentation. Results were indicated as gallic acid (a) and pyrogallol (b) equivalents per $\mathrm{mL}$ of sample. The high content of phenolic acid was recorded at the $15^{\text {th }}$ day of fermentation.

techniques (Tsai et al., 2014). Sripanidkulchai \& Junlatat (2014) also reported the antioxidant properties, and anti-inflammatory effect of phenolic content in P. emblica branch ethanolic extract by maceration and methanolic extract by Soxhlet apparatus. The current study revealed the release of a significant amount of phenolic content from P. emblica fruits by $L$. paracasei mediated fermentation.

\subsection{Acidic content and pH of the FnM during fermentation process}

Analysis of acid content in the consumable fermented product is necessary to ensure the quality of the food. Acetic acid, lactic acid, and the lactic acid equivalent of the total acid content were kinetically measured during the process. The presence of acetic acid was observed, i.e., detectable level, only after 60 days of fermentation. The constant increase in acetic acid content was recorded (Figure 2a). Lactic acid content was found to be higher in Fn-1 $(0.26 \pm 0.01 \mathrm{mg}$ lactic acid $/ \mathrm{mL})$, Fn-3 $(0.23 \pm 0.005 \mathrm{mg}$ lactic acid/mL) and slightly increased in its respective controls (Figure $2 \mathrm{~b}$ ). The total acid content of

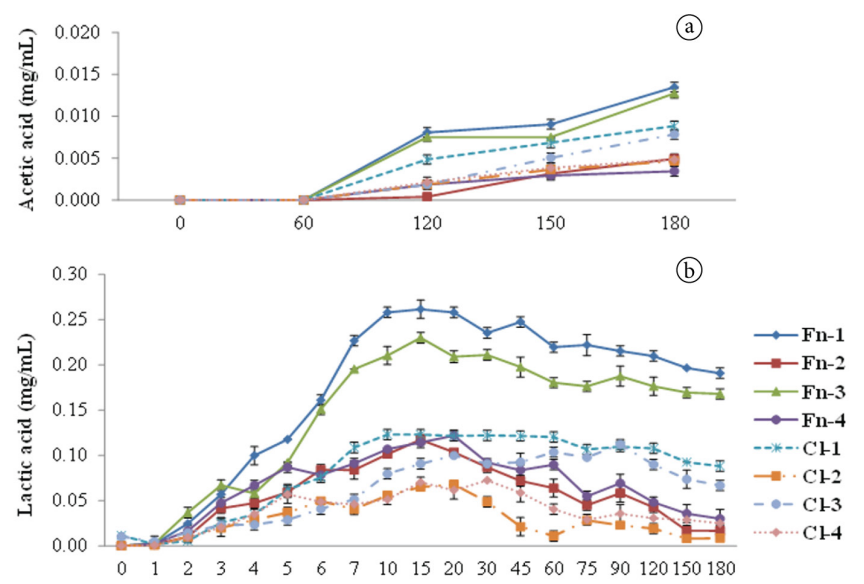

(c)

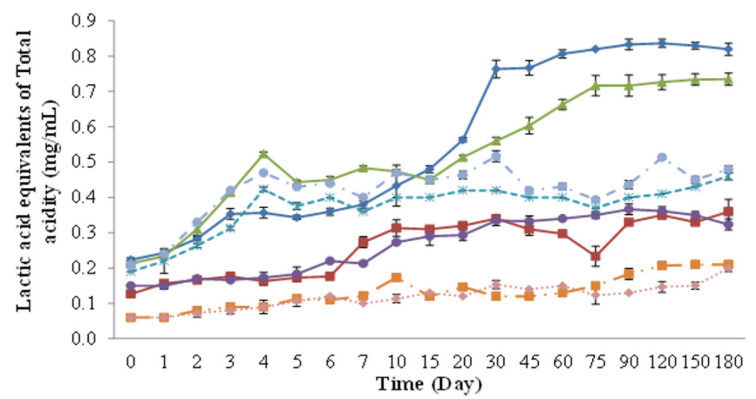

Figure 2. Acidic contents and total acidity of $P$. emblica juice during fermentation. Acetic acid content (a); lactic acid content (b); and lactic acid equivalents of total acid content (c) were measured as detailed in materials and methods. The gradual increase in the acid content was observed during the process.

the ferment was gradually increased in all the reaction. Acidic content was elevated to $0.836 \pm 0.1,0.726 \pm 0.02 \mathrm{mg}$ of lactic acid equivalents per mL Fn-1, 3 reactions, respectively (Figure 2c). Lactic and acetic acids are the metabolites produced by the $\mathrm{LAB}$, which increases acidity, thereby inhibits the growth of several pathogens (Breidt \& Fleming, 1997). Thai community product standard (TCPS) for fermented herbal juice extract (TCPS 481/2547) regulates the quality of food. As per TCPS norms, the $\mathrm{pH}$ of the fermented food should be lower than 4.3. In the current study, the $\mathrm{pH}$ of the mixtures, both control and test were lower than 4.3 (Figure 3).

\subsection{Antioxidant properties and other evaluation of the product}

Antioxidant capacity of fermented products was assessed by ABTS and FRAP assays. Vitamin-C, trolox, and quercetin were used as standards for the evaluation. Fermented products, especially Fn- 1 and Fn-3 showed high antioxidant capacity $(26.55 \pm 0.58$, and $26 \pm 1.3 \mathrm{mg} \mathrm{VCEAC} ; 40.97 \pm 0.9$, and $40.16 \pm 2.0 \mathrm{mg}$ TEAC; $14.85 \pm 0.34$, and $14.54 \pm 0.76 \mathrm{mg}$ QEAC of Fn-1, and Fn-3, respectively) (Figure 4). Fn-1 and Fn-3, reactions consist of the same ingredients except carbon source.

This result suggested that $P$. emblica fermentation with $L$. paracase $i$ was not extensively affected by any of the carbon 
sources, cane sugar or honey, used in the current study (Figure 4). High antioxidant properties were observed in all the reaction at the $15^{\text {th }}$ day of the process (Figure 4 ), which is correlated with polyphenol content of the product (Figure 1). There was no significant level of antioxidant abilities in controls, which indicated that nutrient nourishment was the resultant of fermentation of $P$. emblica fruits by $L$. paracasei. The polyphenol content also supported the above statement (Figure 1). This data also suggested that the nutritional content of cane sugar and honey

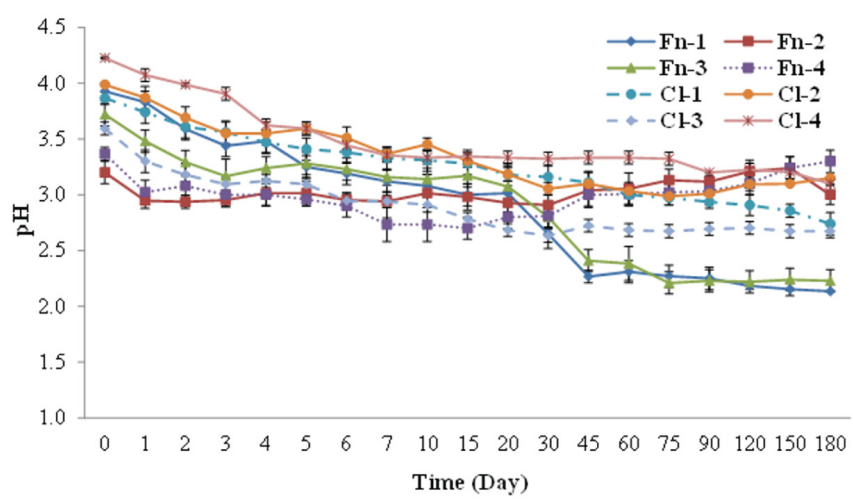

Figure 3. $\mathrm{pH}$ of $P$. emblica juice during fermentation.
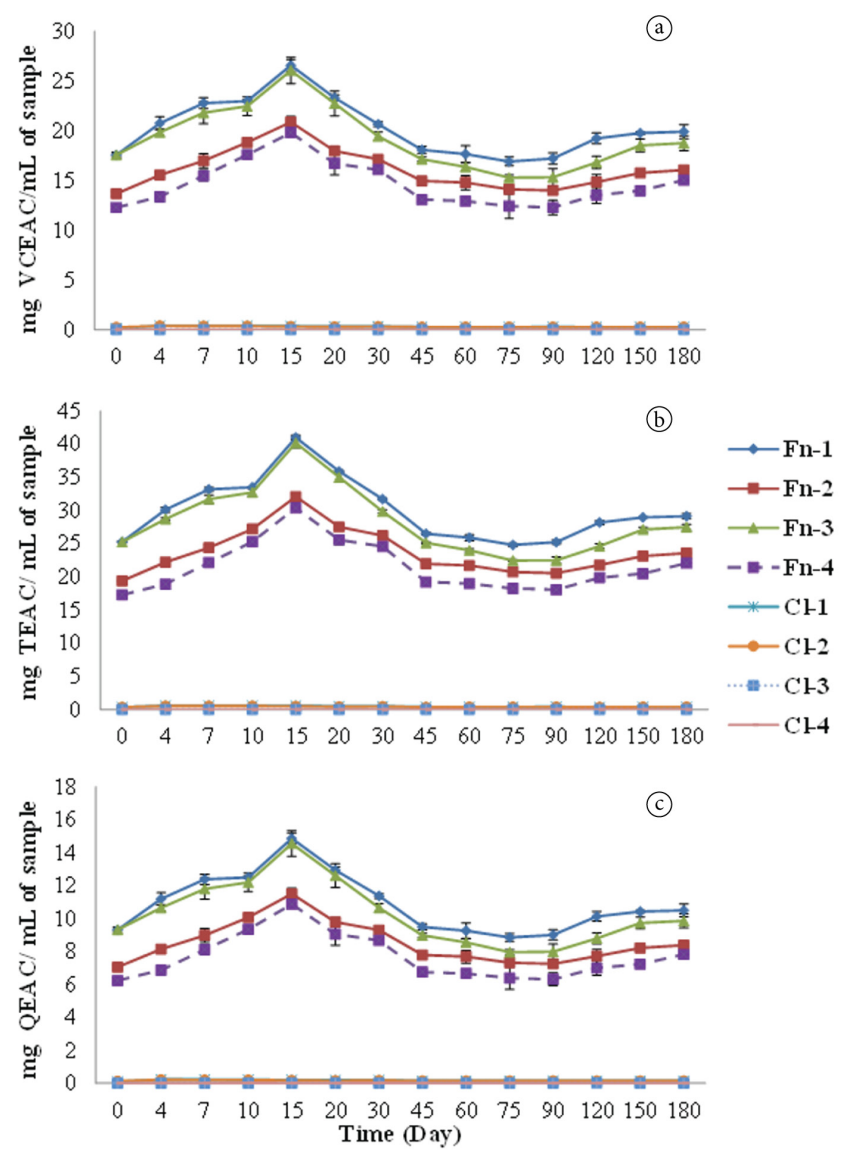

Figure 4. ABTS assay for P. emblica juice during fermentation. Results were represented as mg VCEAC (a); TEAC (b); and QEAC (c) per mL of samples. High activity was recorded at the $15^{\text {th }}$ day of fermentation. did not interfere with the results. The redox property of phenolic components positively influences the antioxidant properties (Rice-Evans et al., 1995).

Antioxidant ability of $P$. emblica extracts depends on the concentration of phenolic content. The polyphenols in P. emblica fruit prevents the oxidation of vitamin $\mathrm{C}$ and maintain its stability (Dhale, 2012). Thus reduction in polyphenols affects the stability of the vitamin C. Antioxidant activity in Fn 1-4 was decreased due to the reduction of vitamin $\mathrm{C}$ and phenolic content after $15^{\text {th }}$ day of fermentation period. The increase in the polyphenolic content and antioxidant activity after 90 days in Fn 1-4 might be due to the completely dissolved content of fermented P. emblica fruit. Luo et al. (2009) have reported the ability of potent antioxidant traits of solvent extracted P. emblica, whereas the current study detailed the fermentation based release of active compounds from $P$. emblica. High reducing power $\left(43.55 \pm 1.45\right.$, and $41.50 \pm 0.40 \mathrm{mg} \mathrm{FeSO}_{4}$ equivalent per $\mathrm{mL}$ of Fn-1, and Fn-3) was recorded at $15^{\text {th }}$ day of fermentation in Fn-1 and Fn-3 reactions (Figure 5a). Thus, FRAP assay results also supported the outcome of ABTS assay. Reducing power is attributed to antioxidant activity used as an important sign of the antioxidant capacity (Oktay et al., 2003).

Tsai et al. (2014) proved the reducing ability of $P$. emblica extract. A noticeable level of the ferric reducing antioxidant property was recorded in the current study with fermentation product. Thus, the L. paracasei assisted fermented product of $P$. emblica could be the good dietary source of antioxidants. The effect of $L$. paracasei mediated $P$. emblica fermented product with the ferrous ion chelating capacity is revealed in Figure 5b,

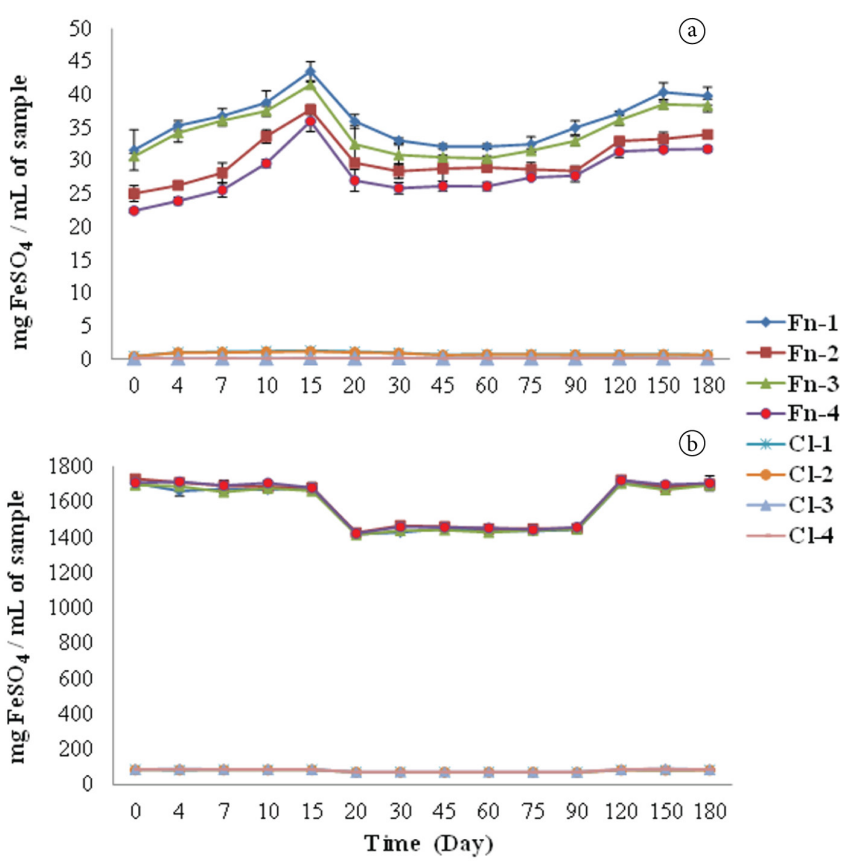

Figure 5. Representation of FRAP (a) and chelating ability assay (b) results of $P$. emblica juice during fermentation. FRAP assay result supports the antioxidant efficiency of product and chelation property of $P$. emblica juice has been proved. High activity was recorded, for both FRAP and chelating ability assay, at the $15^{\text {th }}$ day of fermentation. 
and the results indicated that at the $15^{\text {th }}$ day of fermentation process, all the (Fn 1-4) samples scored high chelating capacity, which might be due to the presence of $P$. emblica. The chelating capacity of honey is slightly higher than that of cane sugar in the controls (Unpublished data). Present results supported the previous report by Tsai et al. (2014), with respect to the chelating property of $P$. emblica. Fermented P. emblica fruit juices are strong enough to stabilize the oxidized form of the metal ion.

The peroxidase enzyme plays an active role in the several metabolic process in plants such as auxins catabolism, and oxidation of cinnamyl alcohols (Quiroga et al., 2000). $\beta$-Glucosidase is an enzyme that hydrolyses a bond between glucose and an aglycone. $\beta$-glucosidase is most often associated with the cell wall of most microorganisms. They are found in a wide number of yeasts, Saccharomyces spp., Candida spp., Aspergillus spp., Hanseniaspora spp., bacteria Oenococcus (Leuconostoc) and in some strain of Lactic acid bacteria. Peroxidase and $\beta$-glucosidase are essential enzymes in human health; its deficiency lead to unpleasant impacts. Dietary supplements of peroxidase and $\beta$-glucosidase help the consumer to develop healthy life. Thus, Fn 1-4 and $\mathrm{Cl} 1-4$ was assessed for quantifying the peroxidase and $\beta$-glucosidase throughout the fermentation period. But both peroxidase and $\beta$-glucosidase was not detectable in Fn 1-4 and its respective control. Overall, the results of the current study suggested that fermentation of $P$. emblica fruit by $L$. paracasei produces high quality of LAFB with independent of carbon source used in this study.

\section{Conclusion}

The current study revealed that LAFB produced by $L$. paracase $i$ mediated fermentation of $P$. emblica fruit is a good dietary product with high polyphenolic content and antioxidant properties. This study also provided the impact of fermentation duration on the quality of the product. As per our knowledge, this is a preliminary study on the use of probiotic-based starter culture for the production of $P$. emblica fruit based LAFB. Further, detailed study of different carbon sources and fine tuning of upstream processes may yield the active principles and enriched high-quality products. The research concerning above is currently in progress.

\section{Acknowledgements}

The authors wish to acknowledge the Faculty of Pharmacy and Chiang Mai University, Chiang Mai, Thailand. This research was partially supported by the CMU Research Grant. BSS gratefully acknowledges the CMU Post-Doctoral Fellowship, the Faculty of Pharmacy, Chiang Mai University, Chiang Mai, Thailand.

\section{References}

Altay, F., Karbancioglu-Güler, F., Daskaya-Dikmen, C., \& Heperkan, D. (2013). A review on traditional Turkish fermented non-alcoholic beverages: microbiota, fermentation process and quality characteristics. International Journal of Food Microbiology, 167(1), 44-56. http:// dx.doi.org/10.1016/j.ijfoodmicro.2013.06.016. PMid:23859403.
Arslan, S. (2015). A review: chemical, microbiological and nutritional characteristics of kefir. CyTA: Journal of Food, 13(3), 340-345. http:// dx.doi.org/10.1080/19476337.2014.981588.

Bergmann, R. S. O., Pereira, M. A., Veiga, S. M. O. M., Schneedorf, J. M., Oliveira, N. M. S., \& Fiorini, J. E. (2010). Microbial profile of a kefir sample preparations: grains in natura and lyophilized and fermented suspension. Food Science and Technology, 30(4), 10221026. http://dx.doi.org/10.1590/S0101-20612010000400029.

Breidt, F., \& Fleming, H. P. (1997). Using lactic acid bacteria to improve the safety of minimally processed fruits and vegetables. Food Technology, 51, 44-51.

Chatterjee, A., Chatterjee, S., Biswas, A., Bhattacharya, S., Chattopadhyay, S., \& Bandyopadhyay, S. K. (2012). Gallic acid enriched fraction of Phyllanthus emblica potentiates indomethacin-induced gastric ulcer healing via e-NOS-dependent pathway. Evidence-Based Complementary and Alternative Medicine, 2012, 487380. PMid:22966242.

Chen, Y.-P., Hsu, C.-A., Hung, W.-T., \& Chen, M.-J. (2015). Effects of Lactobacillus paracasei 01 fermented milk beverage on protection of intestinal epithelial cell in vitro. Journal of the Science of Food and Agriculture. In press. http://dx.doi.org/10.1002/jsfa.7331. PMid:26147180.

Chevallier, A. (1996). The encyclopedia of medicinal plants. London: Dorling Kindersley.

Chiang, S. S., \& Pan, T. M. (2012). Beneficial effects of Lactobacillus paracasei subsp. paracasei NTU 101 and its fermented products. Applied Microbiology and Biotechnology, 93(3), 903-916. http:// dx.doi.org/10.1007/s00253-011-3753-x. PMid:22159887.

Colucci, R., Dragoni, F., Conti, R., Pisaneschi, L., Lazzeri, L., \& Moretti, S. (2015). Evaluation of an oral supplement containing Phyllanthus emblica fruit extracts, vitamin E, and carotenoids in vitiligo treatment. Dermatologic Therapy, 28(1), 17-21. http://dx.doi.org/10.1111/ dth.12172. PMid:25285994.

Decker, E. A., \& Welch, B. (1990). Role of ferritin as a lipid oxidation catalyst in muscle food. Journal of Agricultural and Food Chemistry, 38(3), 674-677. http://dx.doi.org/10.1021/jf00093a019.

Deiana, M., Dessi, M. A., Ke, B., Liang, Y. F., Higa, T., Gilmour, P. S., Jen, L. S., Rahman, I., \& Aruoma, O. I. (2002). The antioxidant cocktail effective microorganism X (EM-X) inhibits oxidant-induced interleukin-8 release and the peroxidation of phospholipids in vitro. Biochemical and Biophysical Research Communications, 296(5), 1148-1151. http://dx.doi.org/10.1016/S0006-291X(02)02061-2. PMid:12207893.

Dhale, D. A. (2012). Pharmacognistic evaluation of Phyllanthus embillica linn (Euphorbiaceae). International Journal of Pharma and Bio Sciences, 3(3), 210-217.

Ekpeghere, K. I., Kim, B. H., Son, H. S., Whang, K. S., Kim, H. S., \& Koh, S. C. (2012). Functions of effective microorganisms in bioremediation of the contaminated harbor sediments. Journal of Environmental Science and Health. Part A, Toxic/Hazardous Substances \& Environmental Engineering, 47(1), 44-53. http://dx.doi.org/10.10 80/10934529.2012.629578. PMid:22217081.

Gao, W., Zhang, L., Feng, Z., Liu, H., Shigwedha, N., Han, X., Yi, H., Liu, W., \& Zhang, S. (2015). Microbial diversity and stability during primary cultivation and subcultivation processes of Tibetan kefir. International Journal of Food Science \& Technology, 50(6), 1468-1476. http://dx.doi.org/10.1111/ijfs.12801.

Habib-ur-Rehman, Yasin, K. A., Choudhary, M. A., Khaliq, N., Attaur-Rahman, Choudhary, M. I., \& Malik, S. (2007). Studies on the chemical constituents of Phyllanthus emblica. Natural Product Research, 21(9), 775-781. http://dx.doi.org/10.1080/14786410601124664. PMid:17763100. 
Jose, J. K., \& Kuttan, R. (1995). Antioxidant activity of Emblica officinalis. Journal of Clinical Biochemistry and Nutrition, 19(2), 63-70. http:// dx.doi.org/10.3164/jcbn.19.63.

Kantachote, D., \& Charernjiratrakul, W. (2008). Selection of lactic acid bacteria from fermented plant beverages to use as inoculants for improving the quality of the finished product. Pakistan Journal of Biological Sciences, 11(22), 2545-2552. http://dx.doi.org/10.3923/ pjbs.2008.2545.2552. PMid:19260331.

Khopde, S. M., Priyadarsini, K. I., Mohan, H., Gawandi, V. B., Satav, J. G., Yakhmi, J. V., Banavaliker, M. M., Biyani, M. K., \& Mittal, J. P. (2001). Characterizing the antioxidant activity of amla (Phyllanthus emblica) extract. Current Science, 81, 185-190.

Khosla, S., \& Sharma, S. (2012). A short description on pharmacogenetic properties of Emblica officinalis. Spatula DD - Peer Reviewed Journal on Complementary Medicine and Drug Discovery, 2(3), 187-193. http://dx.doi.org/10.5455/spatula.20121112072137.

Kıvanç, M., \& Yapıcı, E. (2015). Kefir as a probiotic dairy beverage: determination lactic acid bacteria and yeast. International Journal of Food Engineering, 1(1), 55-60.

Kusirisin, W., Jaikang, C., Chaiyasut, C., \& Narongchai, P. (2009). Effect of polyphenolic compounds from Solanum torvum on plasma lipid peroxidation, superoxide anion and cytochrome P450 2E1 in human liver microsomes. Medicinal Chemistry, 5(6), 583-588. http://dx.doi. org/10.2174/157340609790170443. PMid:20041835.

La Rivière, J. W., \& Kooiman, P. (1967). Kefiran, a novel polysaccharide produced in the kefir grain by Lactobacillus brevis. Archiv für Mikrobiologie, 59(1-3), 269-278. http://dx.doi.org/10.1007/BF00406340. PMid:5602464.

Laloue, H., Weber-Lofti, F., Lucau-Danila, A., \& Gullemat, P. (1997). Identification of ascorbate and guaiacol peroxidase in needle chloroplasts of spruce trees. Plant Physiology and Biochemistry, 35, 341-346.

Luo, W., Zhao, M., Yang, B., Shen, G., \& Rao, G. (2009). Identification of bioactive compounds in Phyllenthus emblica L. fruit and their free radical scavenging activities. Food Chemistry, 114(2), 499-504. http://dx.doi.org/10.1016/j.foodchem.2008.09.077.

McCue, P. P., \& Shetty, K. (2004). Inhibitory effects of rosmarinic acid extracts on porcine pancreatic amylase in vitro. Asia Pacific Journal of Clinical Nutrition, 13(1), 101-106. PMid:15003922.

Miguel, M. G. C. P., Cardoso, P. G., Lago, L. A., \& Schwan, R. F. (2010). Diversity of bacteria present in milk kefir grains using culture-dependent and culture-independent methods. Food Research International, 43(5), 1523-1528. http://dx.doi.org/10.1016/j.foodres.2010.04.031.

Oktay, M., Gulcin, I., \& Kufrevioglu, O. I. (2003). Determination of in vitro antioxidant activity of fennel (Foeniculum vulgare) seed extracts. LWT - Food Science and Technology, 36(2), 263-271. http://dx.doi. org/10.1016/S0023-6438(02)00226-8.

Pellaton, C., Nutten, S., Thierry, A. C., Boudousquié, C., Barbier, N., Blanchard, C., Corthésy, B., Mercenier, A., \& Spertini, F. (2012). Intragastric and intranasal administration of Lactobacillus paracasei NCC2461 modulates allergic airway inflammation in mice. International Journal of Inflammation, 2012, 686739. http://dx.doi. org/10.1155/2012/686739. PMid:22762009.

Prachyakij, P., Schnurer, J., Charernjiratrakul, W., \& Kantachote, D. (2007). Selection and identification of lactic acid bacteria that inhibit yeast contaminants isolated from fermented plant beverages. Songklanakarin Journal of Science and Technology, 29(Suppl 2), 211-218.
Quiroga, M., Guerrero, C., Botella, M. A., Barceló, A., Amaya, I., Medina, M. I., Alonso, F. J., de Forchetti, S. M., Tigier, H., \& Valpuesta, V. (2000). A tomato peroxidase involved in the synthesis of lignin and suberin. Plant Physiology, 122(4), 1119-1127. http://dx.doi. org/10.1104/pp.122.4.1119. PMid:10759507.

Rice-Evans, C. A., Miller, N. J., Bolwell, P. G., Bramley, P. M., \& Pridham, J. B. (1995). The relative antioxidant activities of plant-derived polyphenolic flavonoids. Free Radical Research, 22(4), 375-383. http://dx.doi.org/10.3109/10715769509145649. PMid:7633567.

Rodrigues, K. L., Caputo, L. R., Carvalho, J. C., Evangelista, J., \& Schneedorf, J. M. (2005). Antimicrobial and healing activity of kefir and kefiran extract. International Journal of Antimicrobial Agents, 25(5), 404-408. http://dx.doi.org/10.1016/j.ijantimicag.2004.09.020. PMid:15848295.

Romero, A. M., Doval, M. M., Sturla, M. A., \& Judis, M. A. (2004). Antioxidant properties of polyphenol-containing extract from soybean fermented with Saccharomyces cerevisiae. European Journal of Lipid Science and Technology, 106(7), 424-431. http://dx.doi. org/10.1002/ejlt.200400953.

Ross, R. P., Morgan, S., \& Hill, C. (2002). Preservation and fermentation: past, present and future. International Journal of Food Microbiology, 79(1-2), 3-16. http://dx.doi.org/10.1016/S0168-1605(02)00174-5. PMid:12382680.

Singhatong, S., Leelarungrayub, D., \& Chaiyasut, C. (2010). Antioxidant and toxicity activities of Artocarpus lakoocha Roxb. heartwood extract. Journal of Medicinal Plants Research, 4, 947-953.

Sripanidkulchai, B., \& Junlatat, J. (2014). Bioactivities of alcohol based extracts of Phyllanthus emblica branches: antioxidation, antimelanogenesis and anti-inflammation. Journal of Natural Medicines, 68(3), 615-622. http://dx.doi.org/10.1007/s11418-0140824-1. PMid:24557876.

Suwannalert, P., Rattanachitthawat, S., Chaiyasut, C., \& Riengrojpitak, S. (2010). High levels of 25-hydroxyvitamin $\mathrm{D}_{3}\left[25(\mathrm{OH}) \mathrm{D}_{3}\right]$ and a-tocopherol prevent oxidative stress in rats that consume Thai brown rice. Journal of Medicinal Plants Research, 4(2), 120-124.

Swain, M. R., Anandharaj, M., Ray, R. C., \& Rani, R. P. (2014). Fermented fruits and vegetables of Asia: a potential source of probiotics. Biotechnology Research International, 2014, 250424. http://dx.doi. org/10.1155/2014/250424. PMid:25343046.

Tsai, C. C., Chou, C. H., Liu, Y. C., \& Hsieh, C. W. (2014). Ultrasoundassisted extraction of phenolic compounds from Phyllanthus emblica L. and evaluation of antioxidant activities. International Journal of Cosmetic Science, 36(5), 471-476. http://dx.doi.org/10.1111/ ics.12143. PMid:24888887.

Wassenberg, J., Nutten, S., Audran, R., Barbier, N., Aubert, V., Moulin, J., Mercenier, A., \& Spertini, F. (2011). Effects of Lactobacillus paracasei ST11 on a nasal provocation test with grass pollen in allergic rhinitis. Clinical and Experimental Allergy, 41(4), 565-573. http://dx.doi. org/10.1111/j.1365-2222.2011.03695.x. PMid:21395878.

Yang, J. H., Maub, J. L., Kob, P. T., \& Huang, L. C. (2000). Antioxidant properties of fermented soybean broth. Food Chemistry, 71(2), 249254. http://dx.doi.org/10.1016/S0308-8146(00)00165-5.

Yang, X., Yan, F., Huang, S., \& Fu, C. (2014). Antioxidant activities of fractions from longan pericarps. Food Science and Technology, 34(2), 341-345. http://dx.doi.org/10.1590/S0101-20612014005000034. 


\section{Supplementary Material}

Table 1S. Color, odor, taste, turbidity and gas formation during the fermentation process of $P$. emblica. Information was collected by direct observation of fermentation and control reactors. Fn.: Fermentation; Cl.: Control.

\begin{tabular}{|c|c|c|c|c|c|}
\hline $\begin{array}{c}\text { Duration } \\
\text { (Day) }\end{array}$ & Color & Odor & Taste & Gas & Remarks \\
\hline 0 & $\begin{array}{l}\text { DB: Fn-1, 2; Cl-1, } \\
\text { PY: Fn-3, 4; Cl-3, } 4\end{array}$ & $\begin{array}{l}\text { Similar to pickled } \\
\text { tamarind }\end{array}$ & $\begin{array}{c}\text { Slightly } \\
\text { sweet }\end{array}$ & No gas & \\
\hline 4 & $\begin{array}{l}\text { DB: Fn-1, 2; Cl-1, } 2 \\
\text { PY: Fn-3, 4; Cl-3, } 4\end{array}$ & $\begin{array}{l}\text { Similar to pickled } \\
\text { tamarind and sour; }\end{array}$ & Sour & $\begin{array}{l}\text { plenty of gas in Fn-1, } 2 \text { and } \\
\text { Cl-1,2 }\end{array}$ & $\begin{array}{l}\text { Filmy and bubbles were } \\
\text { found at top of the juice in } \\
\text { Fn-2, 4, Cl-2, } 4\end{array}$ \\
\hline 7 & $\begin{array}{l}\text { DB: Fn-1, 2; Cl-1, } 2 \\
\text { PY: Fn-3, 4; Cl-3, } 4\end{array}$ & $\begin{array}{l}\text { Similar to pickled } \\
\text { tamarind and sour; }\end{array}$ & Sour & $\begin{array}{l}\text { plenty of gas in Fn-1,2 and } \\
\text { Cl-1,2 }\end{array}$ & $\begin{array}{l}\text { Filmy and bubbles were } \\
\text { found at top of the juice in } \\
\text { Fn-2, } 4, \mathrm{Cl}-2,4\end{array}$ \\
\hline 10 & $\begin{array}{l}\text { DB: Fn-1, 2; Cl-1, } 2 \\
\text { PY: Fn-3, 4; Cl-3, } 4\end{array}$ & $\begin{array}{l}\text { Similar to pickled } \\
\text { tamarind and sour; }\end{array}$ & Sour & $\begin{array}{l}\text { plenty of gas in Fn-1, } 2 \text { and } \\
\text { Cl-1,2 }\end{array}$ & $\begin{array}{l}\text { Filmy and bubbles were } \\
\text { found at top of the juice in } \\
\text { Fn-2, } 4, \mathrm{Cl}-2,4\end{array}$ \\
\hline 15 & $\begin{array}{l}\text { DB: Fn-1, 2; Cl-1, } 2 \\
\text { DY: Fn-3, 4; Cl-3, } 4\end{array}$ & $\begin{array}{l}\text { Similar to pickled } \\
\text { tamarind and sour; }\end{array}$ & Sour & $\begin{array}{l}\text { plenty of gas in Fn-1, } 2 \text { and } \\
\text { Cl-1,2 }\end{array}$ & $\begin{array}{l}\text { Filmy and bubbles were } \\
\text { found at top of the juice in } \\
\text { Fn-2, } 4, \mathrm{Cl}-2,4\end{array}$ \\
\hline 20 & $\begin{array}{l}\text { DB: Fn-1, 2; Cl-1, } 2 \\
\text { DY: Fn-3, 4; Cl-3, } 4\end{array}$ & $\begin{array}{l}\text { Similar to pickled } \\
\text { tamarind and sour; }\end{array}$ & Sour & $\begin{array}{l}\text { plenty of gas in Fn-1, } 2 \text { and } \\
\text { Cl-1,2 }\end{array}$ & $\begin{array}{l}\text { Filmy and bubbles were } \\
\text { found at top of the juice in } \\
\text { Fn-2, } 4, \mathrm{Cl}-2,4\end{array}$ \\
\hline 30 & $\begin{array}{l}\text { DB: Fn-1, 2; Cl-1, } 2 \\
\text { DY: Fn-3, 4; Cl-3, } 4\end{array}$ & $\begin{array}{l}\text { Similar to pickled } \\
\text { tamarind and sour; }\end{array}$ & Sour & $\begin{array}{l}\text { plenty of gas in Fn-1, } 2 \text { and } \\
\text { Cl-1,2 }\end{array}$ & $\begin{array}{l}\text { Filmy and bubbles were } \\
\text { found at top of the juice in } \\
\text { Fn-2, 4, Cl-2, } 4\end{array}$ \\
\hline 45 & $\begin{array}{l}\text { DB: Fn-1, 2; Cl-1, } 2 \\
\text { DY: Fn-3, 4; Cl-3, } 4\end{array}$ & $\begin{array}{l}\text { Similar to pickled } \\
\text { tamarind and sour; }\end{array}$ & Strong sour & Reduced gas & $\begin{array}{l}\text { Filmy and bubbles were } \\
\text { found at top of the juice in } \\
\text { Fn-2, } 4, \mathrm{Cl}-2,4\end{array}$ \\
\hline 60 & $\begin{array}{l}\text { DB: Fn-1, 2; Cl-1, } 2 \\
\text { DY: Fn-3, 4; Cl-3, } 4\end{array}$ & $\begin{array}{l}\text { Similar to pickled } \\
\text { tamarind and sour; }\end{array}$ & Strong sour & Reduced gas & $\begin{array}{l}\text { Fn-2, 4, and Cl-2, } 4 \text { smell } \\
\text { like alcohol, filmy layer was } \\
\text { found in all Fn. }\end{array}$ \\
\hline 75 & $\begin{array}{l}\text { DB: Fn-1, 2; Cl-1, } 2 \\
\text { DY: Fn-3, 4; Cl-3, } 4\end{array}$ & $\begin{array}{l}\text { Similar to pickled } \\
\text { tamarind and sour; }\end{array}$ & Sour & Reduced gas & $\begin{array}{l}\text { Fn-2, 4, and Cl-2, } 4 \text { smell } \\
\text { like alcohol, filmy layer was } \\
\text { found in all Fn. }\end{array}$ \\
\hline 90 & $\begin{array}{l}\text { DB: Fn-1, 2; Cl-1, } 2 \\
\text { DY: Fn-3, 4; Cl-3, } 4\end{array}$ & $\begin{array}{l}\text { Similar to pickled } \\
\text { tamarind and sour; }\end{array}$ & Sour & No gas & $\begin{array}{l}\text { Fn-2, 4, and } \mathrm{Cl}-2,4 \text { smell } \\
\text { like alcohol, filmy layer was } \\
\text { found in all Fn. }\end{array}$ \\
\hline 120 & $\begin{array}{l}\text { DB: Fn-1, 2; Cl-1, } 2 \\
\text { DY: Fn-3, 4; Cl-3, } 4\end{array}$ & $\begin{array}{l}\text { Similar to pickled } \\
\text { tamarind and sour; }{ }^{*}\end{array}$ & Sour & No gas & $\begin{array}{l}\text { Fn-2, 4, and } \mathrm{Cl}-2,4 \text { smell } \\
\text { like alcohol, filmy layer was } \\
\text { found in all Fn. }\end{array}$ \\
\hline 150 & $\begin{array}{l}\text { DB: Fn-1, 2; Cl-1, } 2 \\
\text { DY: Fn-3, 4; Cl-3, } 4\end{array}$ & $\begin{array}{l}\text { Similar to pickled } \\
\text { tamarind and sour;* }\end{array}$ & Sour & No gas & $\begin{array}{l}\text { Fn-2, 4, and Cl-2, } 4 \text { smell } \\
\text { like alcohol, filmy layer was } \\
\text { found in all Fn. }\end{array}$ \\
\hline 180 & $\begin{array}{l}\text { DB: Fn-1, 2; Cl-1, } 2 \\
\text { DY: Fn-3, 4; Cl-3, } 4\end{array}$ & $\begin{array}{l}\text { Similar to pickled } \\
\text { tamarind and sour; }\end{array}$ & Sour & No gas & $\begin{array}{l}\text { Fn-2, 4, and Cl-2, } 4 \text { smell } \\
\text { like alcohol, filmy layer was } \\
\text { found in all Fn. }\end{array}$ \\
\hline
\end{tabular}

Notes: Dark brown = DB; Pale yellow = PY; Dark yellow = DY. ${ }^{\star} \mathrm{Bad}$ odor in Cl-2; All the Fn and Cl samples were turbid during the fermentation process of P. emblica . 